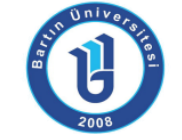

ISSN: 1308-7177
Bartin University

Journal of Faculty of Education

Volume 6, Issue 3, p. 840-858, October 2017

BARTIN - TURKEY

\title{
Ortaokul Öğrencilerinin Toplumsal Değerlere Yönelik Bakış Açılarının Farklı Değişkenlere Göre İncelenmesi
}

\author{
Sinem ERGÜN KAPLAN, Doktora Öğrencisi, Necmettin Erbakan Üniversitesi Eğitim Fakültesi, sinem.ergun01@gmail.com, \\ ORCID: http://orcid.org/0000-0002-4575-918X \\ Süleyman Alpaslan SULAK, Yrd. Doç. Dr., Necmettin Erbakan Üniversitesi Eğitim Fakültesi, sulak@konya.edu.tr, \\ ORCID: http://orcid.org/0000-0001-9716-9336
}

Öz: Bu çalışmanın amacı ortaokul öğrencilerin toplumsal değerlere yönelik bakış açılarını ortaya çıkarmaktır. Araştırma 2016-2017 akademik yılında Konya ili Meram ilçesinde bulunan beş ortaokulda öğrenim gören öğrencilerden basit tesadüfi örnekleme yolu ile seçilen 208 öğrenci üzerinde uygulanmıştır. Araştırmada hem nitel hem nicel yöntemlerinin birlikte kullanıldığı karma desen kullanılmıştır. Araştırmanın nicel boyutunda veri toplama aracı olarak Toplumsal Değerlere Yönelik Algı Ölçeği kullanılırken nitel boyutunda da araştırmacı tarafından geliştirilen dört sorudan oluşan görüşme formu kullanılmıştır. Elde edilen nicel veriler bağımsız örneklem $t$ testi ve tek faktörlü varyans analizi (ANOVA) ile nitel veriler ise betimsel analiz yöntemiyle çözülmüştür. Araştırmanın sonucunda öğrencilerin toplumsal değerlerle ilişkin algısı, cinsiyetlerine ve annelerinin eğitim durumlarına göre anlamlı farklılık gösterirken, babalarının eğitim durumları, kardeş sayılarında ve karne not ortalamalarında anlamlı bir farklılık bulunamamıştır.

Anahtar Kelimeler: aile, değer, dürüstlük, sorumluluk, toplumsal değer, vatan

\section{The Examination of Perception of Social Values of Elemantary School Students According to Different Variables}

\begin{abstract}
The purpose of this study is to identify the students' perceptions of social value. The study was carried 208 students on five school by random in Meram in Konya in 2016-2017 education year. Mixed method which is used both quantitative method and qualitative method is used in this research. The scale of students' perceptions of social value was used in quantitative part of research, four questions which prepared by researcher were used qualitative method part of research. Data is analyzed with independent samples t-test, ANOVA and descriptive analysis. According to the findings, it is found that there is a significant difference between the students' perceptions of social values and their genders, mother's educational background but there is not a significant difference between the students' perceptions of social values and their father's educational background, the number of sister/brother, average of school report.
\end{abstract}

Key Words: family, homeland, honesty, responsibility, social values, values 


\section{GíRiş}

Eğitim bugüne kadar değişik şekillerde tanımlanmıştır. Ertürk'e (1975) göre eğitim; bireyin davranışlarında kendi yaşantısı yoluyla ve istendik olarak değişim oluşturma sürecidir. Bu tanıma benzer başka bir tanıma göre eğitim; kişinin beyni, vücudu, sosyal yeteneklerinin, davranışının en uygun şekilde ya da istenilen bir yönde geliştirilmesi, ona bir takım amaçlara dönük yeni yetenekler, davranışlar, bilgiler kazandırılması yolundaki çalışmaların tümüdür (Akyüz, 2008). Milleti millet yapan ortak değerlerin korunmasında, ilerlemesinde, diğer nesillere taşımasında, ayrıca fert ve toplumun maddi, manevi olarak kalkınmasında yardımcı olacak araçların kazandırımasıdır (Demirtaş, 2010). Fidan'a (2012) göre ise eğitim insanları belirli hedeflere göre yetiştirme sürecidir. Sonuç olarak eğitim bireylere bir takım amaçları kazandırmak amacıyla yapılan değişikliklerin ve uygulamaların tümü olarak ifade edilebilir.

Eğitimin gerçekleştirildiği yerler olan eğitim kurumlarının programlarında açık olarak ifade edilen veya edilmeyen değerleri öğretmek, öğrencileri belirlenen kurallar doğrultusunda disipline etmek, onların ahlakî gelişimine olumlu katkıda bulunmak ve karakterini olumlu yönde etkilemek gibi görevleri bulunmaktadır (Akbaş, 2008). Bacanlı'ya göre eğitim kurumlarının amaçları incelendiğinde birçoğunun sağlığına dikkat etme, vatansever olma, temiz olma, yaratıcı olma, düzenli olma, adil olma, girişimci olma gibi birçok değeri kapsadığı görülmektedir. Sosyal eğilimler, benlik algısı, değerler, takdir duyguları, ahlak, inançlar, etik, beklentiler ve tutumlar duyuşsal eğitimin içindedir (Bacanlı, 2005). Buna göre değerlerin eğitimin duyuşsal boyutunu içerdiği ve eğitim kurumlarındaki eğitim programlarının hedefleri içinde yer aldığı anlaşıımaktadır. Ülkemizde de uygulanan eğitim programında önce bireyin gelişimi ve dolaylı olarak Türk Toplumunun ilerlemesi amaçlanmaktadır. Bu amaç doğrultusunda 2005 yılında ilköğretim programında değişiklikler yapılmıştır. Sosyal bilgiler programında geniş yer verilen değer eğitimi bu değişikliklerin parçasını oluşturmaktadır (Baydar, 2009). Bu açıdan bakıldığında Sosyal Bilgiler dersi değer eğitimi açısından etkili derslerden biri olarak görülmektedir. Öğrencilerde sosyal eleştiri yeteneği ve düşünme becerilerine bağlı olarak karar verme ve katılım becerisi geliştirme; öğrencilerde demokratik yapı ve değerlere ilişkin algı oluşturma Sosyal Bilgiler dersinin amaçlar içerisindedir (Michealis ve Garcia, 1996). Ayrıca Sosyal Bilgiler dersi toplumsal yapı içerisinde bireysel, toplumsal ve kültürel kimliğin farkında olan; ülkesini ve dünyayı ilgilendiren sorunlara karşı duyarlı olan; problem çözme yeteneğine sahip olan ve karar verebilen; demokratik değerleri ve yaşama bilincini benimsemiş bireyler yetiştirmeyi amaçlamaktadır (Yaşar, 2008). Sosyal beceriler ve değerler üzerinde duran bu ders sadece bilişsel amaçları değil duyuşsal amaçları da kazandırmaya çalışmaktadır (Bacanlı, 2005). Bu sebeplerden dolayı Sosyal bilgiler dersi gerek içeriğinin tarihsel bir nitelik taşıması, gerekse değişik kültür ve yaşam hikâyelerini anlatması ve çok disiplinli bir yapıya sahip olması açısından değer öğretimi bakımından önemlidir (Kan, 2010).

Değerler hakkında bugüne kadar pek çok araştırma yapılmasına rağmen, değerlerin tam olarak ne içerdiğine ilişkin henüz ortak bir görüşe varılamamıştır. Değerlerin çeşitli tanımları yapılmıştır. Günlük dilden başlayarak felsefe, pedagoji, sosyoloji ve teoloji gibi farklı ilmî disiplinlerde yer alan bir kavram olan değer kavramı (Ayaz, 2015) sözlükte "Bir şeyin önemini belirlemeye yarayan soyut ölçü, bir şeyin değdiği karşılık, kıymet olarak ifade 
edilmiştir" (TDK, 2007). Değer başka soyut anlamda bir şeyin arzu edilebilir veya edilemez olduğu bir dizi inanç olarak da tanımlanmaktadır (Güngör, 2000). Bir durumu diğerine tercih etme olarak tanımlanmasıyla (Uysal, 2008) değerin bir kıyas aracı olarak ifade edildiği düşünülebilir. Toplumdaki önemi açısından değer, davranışlara kaynaklık eden, onları yargılamaya yardım eden ve toplumu ayakta tutan temel sistem olarak tanımlanmıştır (Alan, 2014). Değerlerin bir kimse için tercihlerinde ve fikirlerinde rehber görevi gördüğü ve o kimseyi hedefe veya doğruya götüren düşünceler topluluğu olarak da ifade edilebilir (Başol, 2016). Aynı zamanda hayatımızı nasıl sürdürdüğümüzü, düzenlediğimizi ve buna bağlı olan deneyimlerimiz ile ilgili fikirlerimizi de betimler (Kirmanoğlu, 2016). Neyin güzel neyin çirkin, neyin iyi neyin kötü, neyin doğru neyin yanlış olduğuna dair kararlarımızı değerlerin kılavuzluğunda veririz (Ulusoy ve Arslan, 2016). Daha genel bir tanımla değer; bireyin maddi ve manevi durumlarla karşı karşıya kaldığında geliştirdiği, olaylar, nesneler ve olgular arasında bir tercih yaptığında birine diğerinden fazla önem verdiği; bireyin iç dünyasında başlayan ve davranışlarını etkileyen, birey için önemli olan anlayış, tutum, inanış ve yaşamsal ilkeler toplamıdır (Bolat, 2016). Değerlerin tanımlarıyla nasıl tam görüş birliğine varılamamışsa, değerlerin sınıflandırılmasında da aynı görüş farklılığı görülmektedir.

Değerler bugüne kadar birçok şekilde sınıflanmıştır. Değerlerin sınıflandırılmasında ilklerden biri olan ve daha sonra yapılan çalışmalarda da öncülük gösteren Spranger (1928) değerleri ilk gruplayanlardandır. Ona göre değerler bilgiye, muhakemeye ve eleştirel düşünmeye önem veren bilimsel değer, parasal amaçları ve ona ulaşan araçları kapsayan ekonomik değer, deneyimleri, tercihleri ve kabulleri içine alan estetik değer, toplum-insan arasındaki ilişkilerdeki eğilimleri inceleyen sosyal değer, güç, liderlik gibi kuvvet kavramıyla ilgili değerleri içinde barındıran politik değer ve dünya ile evren hakkındaki genel inançlara dair değerleri içine alan dini değerler olmak üzere altı gruba ayrılmaktadır. Bu değerlere ek olarak Güngör ahlaki değerleri de eklemiştir. Ona göre ahlaki değerler, dürüst olma gibi değerlerdir (Güngör, 2000). Rokeach (1973) ise değerleri amaçsal (terminal) ve araçsal (instrumental) olmak üzere toplam on sekiz değeri iki kategoride sınıflandırmış ve iki değer sistemi arasındaki ilişkiden söz etmiştir. Kişinin hayatında ulaşmak istediği durumu (özgürlük, aile güvenliği) amaçsal; amaçsal değerlere ulaşmak için benimsenen hareketler ise araçsal değerler olarak belirtilmiştir (Dilmaç ve Bircan, 2014). Buna göre amaç değerler, genelde soyut ve evrensel özellikler gösterir. Araçsal değerler ise daha somut ve değişkendir. Son zamanlarda yapılan bir değer sınıflandırması da Dilmaç ve Arıcak ( 2012) tarafından yapılmıştır. Bu sınıflamaya göre değerler; toplumsal değerler, kariyer değerleri, entelektüel değerler, maneviyat (spritual values), materyalistik değerler(materialistic values), insan onuru (honor of humanity), romantik değerler (romantic values), özgürlük (freedom) ve fütüvvet (Futuwwat /munificence\&courage) olmak üzere dokuz gruba ayrımıştır. Ayrıca değerler haz ve acı yönüyle hazcı değerler; faydalı, zararlı yönüyle de faydacı değerler bulunmaktadır. Değerler, ayriyeten şekilsel açıdan olumluolumsuz, mutlak-göreli ve öznel-nesnel olarak farklı sınıflara ayrıımıştır (Aydın ve Gürler, 2014).

Değerler farklı şekilde sınıflandığı görülmüştür. Değerlerin farklı sınıflamalarına rağmen bazı değerlerin sınıflandırmalarda ortak ele alındığı görülmüştür. Bu değerlerden biri daha iyi bir toplumun oluşması için toplumun çoğunluğu tarafından paylaşılan toplumsal değerler olarak isimlendirilmektedirler (Türkkahraman, 2014).Toplumsal değerler, belirli bir toplumda oluşan, ortak olarak kabul edilen, düşünce ve kuralların uygulama şeklini gösteren ölçütlerdir. Çoğunlukla beğeniyi, ahlakı ve inançları esas alır. Toplumsal değerler, toplumların tarihsel gelişimiyle oluşur. Birey doğduğu zaman yaşadığı toplumun değerlerini görür. Değerler, bir toplumdaki bireyler ve gruplar tarafından benimsenen, düşünceler, kurallar, davranışlar ve maddi ögelerden meydana geldiği için; maddi ve manevi niteliklere de sahiptir (Ceylan, 2012). Bir başka ifadeyle toplumların uzun yıllar biriktirdikleri toplumsal değerler, onların kültür meyveleridir. Toplumsal değerler, toplumların parmak izi gibidir ve insan davranışlarının 
köklerini oluşturur. Bireylerin hayatlarında ve etraflarındaki yaşananları anlamlandırmada belirleyici olan değerler, bireye toplumda ne yapması gerektiğini bildiren ve belirleyen hükümlerdir (Canatan, 2008). Toplumsal değerlerin toplumlarla bütünleştiği buradan anlaşılabilir.

Toplumsal değerlerin, bir topluma ait olmasının en önemli koşulu beraber yaşama ve etkileşim halinde olmadır. Bu nedenle değerlerin değişmesi hiç kolay değildir. Toplumsal değerlerin, toplumdaki bireyleri birleştirme ve toplumları birbirinden ayırma özelliği bulunmaktadır. Toplumsal değerler, bireylerin birlikte yaşamalarını sağlayan kuralları içine alarak bireyleri bir araya getirirken, her toplumun farklı bir yaşam biçiminin olmasından dolayı toplumları birbirinden ayırmaktadır (Ersoy, 2006).

Toplumsal değerlere MEB tarafından hazırlanmış 1948 tarihli ilkokul programında ve 1968 tarihli ilkokul programlarında da yer verilmiştir. 1948 tarihli ilkokul programında bağlıık, sevgi, saygı, yardımlaşma, bireylerin içinde bulunduklarını yaşama şartlarını iyileştirme isteğini duyurma, sağlık, tutumluluk, temizlik, ev ve çevre güzelliği, barış, milli bilinç gibi değerler yer alırken(MEB, 1948); 1968 tarihli ilkokul programında ise 1948 tarihindeki gibi barış ve muadili değerler başta olmak üzere cesurluk, konukseverlik, doğruluk, hoşgörülük gibi değerlere yer almıştır (MEB, 1968).

Toplumları birbirinden ayıran değerler toplumlara göre farklılık göstermektedir. Örneğin; Çin Halk Cumhuriyeti'nin temel toplumsal değerleri; uyum, iyilik, doğruluk, kibarlık, bilgelik, dürüstlük, sadakat ve aileye/ ataya saygı olarak belirtilmiştir (Lihua, 2013).

Topluma ilişkin değerler, içtimai değerler, maşerî değerler ve sosyal değerler anlamlarına gelen toplumsal değerlerin (TDK, 2007) grupların ve bireylerin toplumsal önemlerini değerlendirme, toplumda çeşitli tabakalaşmaları belirlemek; bireye çevresinin diğerlerinin bakış açısına göre nereyi işgal etmekte olduğunu öğretmek; toplumdaki maddi unsurlardan hangisinin istemeye değer olduğunu belirleyerek bunlar üzerindeki isteği harekete geçirmek; topumdaki olması gereken düşünme ve davranma şeklini belirlemek, toplumsal rollerin seçilmesine ve uygulanmasına rehberlik ederek toplumsal dayanışmanın olmasını sağlamaya çalışmak şeklinde işlevleri bulunmaktadır (Tezcan, 1987).

Bunlara göre toplumsal değerler insanlarla ilişkili olup; toplumu ve bireyi yakından etkilemektedir. Bu araştırmanın amacı ortaokul öğrencilerin toplumsal değerlere bakış açılarını ortaya çıkarmaktır. Ortaokul öğrencilerinin sahip oldukları toplumsal değerlerin belirlenmesi ile okul yöneticileri ve eğitmenleri tarafından öğrencilerin toplumsal ihtiyaçlarının daha kolay karşılanması araştırmanın önemini göstermektedir. Ayrıca araştırmanın ortaokul öğrencileri için program geliştirme uzmanlarına fayda sağlayacağı düşünülmektedir. Bu amaç kapsamında aşağıdaki alt problemlere cevap aranmıştır:

(1) Meram ilçesindeki ortaokul öğrencilerinin cinsiyetleriyle toplumsal değerleri algılama ölçeğinden aldıkları puanlar arasında anlamlı bir farklılık var mıdır?

(2) Meram ilçesindeki ortaokul öğrencilerinin annelerinin eğitim durumlarıyla toplumsal değerleri algılama ölçeğinden aldıkları puanlar arasında anlamlı bir farklılık var mıdır?

(3) Meram ilçesindeki ortaokul öğrencilerinin babalarının eğitim durumlarıyla toplumsal değerleri algılama ölçeğinden aldıkları puanlar arasında anlamlı bir farklıık var mıdır?

(4) Meram ilçesindeki ortaokul öğrencilerinin kardeş sayılarıyla toplumsal değerleri algılama ölçeğinden aldıkları puanlar arasında anlamlı bir farklılık var mıdır? 
(5) Meram ilçesindeki ortaokul öğrencilerinin karne ortalamalarıyla toplumsal değerleri algılama ölçeğinden aldıkları puanlar arasında anlamlı bir farklılık var mıdır?

(6) Meram ilçesindeki ortaokul öğrencilerinin aile konusundaki duygu ve düşünceleri nelerdir?

(7) Meram ilçesindeki ortaokul öğrencilerinin dürüstlük konusundaki duygu ve düşünceleri nelerdir?

(8) Meram ilçesindeki ortaokul öğrencilerinin sorumluluk konusundaki duygu ve düşünceleri nelerdir?

(9) Meram ilçesindeki ortaokul öğrencilerinin vatan konusundaki duygu ve düşünceleri nelerdir?

\section{YÖNTEM}

\subsection{Araştırma Modeli}

Bu çalışmada hem nicel, hem de nitel araştırma yöntemlerinin birlikte kullanıldığı karma desenin açıklayıcı araştırma modeli kullanılmıştır (Sönmez, Alacapınar, 2014). Araştırmaya önce nicel araştırma yönteminin betimsel çalışmayla başlanmıştır. Karasar (2006)'a göre, olayların, objelerin, varlıkların, kurumların, grupların ve çeşitli alanların ne olduğunu betimlemeye, açıklamaya çalışan çalışmalar betimsel çalışmalardır. Betimsel çalışmanın ardından nitel araştırmanın yarı yapılandırıımış görüşme tekniği ile veriler toplanmıştır. Yarı yapılandırılmış görüşme tekniği görüşme tekniğinin bir çeşidi olup, araştırmacı tarafından hazırlanan sorular üzerinde yanıtlayıcının kısmen düzeltme hakkının olduğu tekniktir (Sönmez, Alacapınar, 2014).

\subsection{Evren ve Örneklem}

$\mathrm{Bu}$ araştırmanın evrenini Konya ili Meram ilçesindeki ortaokul öğrencileri oluşturmaktadır. Araştırma 2016-2017 akademik yılında Konya ili Meram ilçesine bağlı bir ortaokulun beşinci sınıfından sekizinci sınıfa kadar öğrenim gören ve basit tesadüfi örnekleme yoluyla belirlenen 208 öğrenci üzerinde yapılmıştır. Öğrencilerin sınıflara göre dağılımı Tablo 1 'de gösterilmiştir.

Tablo 1

\section{Öğrencilerin Sınıflara Göre Dağılımı}

\begin{tabular}{llll}
\hline 5.sınıf & 6. sinıf & 7. sinıf & $\mathbf{8 . s i n i f}$ \\
\hline 62 & 64 & 44 & 38
\end{tabular}

208 öğrenci arasından şans yoluyla belirlenen ve gönüllü olan 9 öğrenciyle yarı yapılandırılmış odak grup görüşmesi yapılmıştır. Görüşme yapılan öğrencilerin sınıflara göre dağılımı Tablo 2' de gösterilmiştir. 
Tablo 2

Görüşme Yapılan Öğrencilerin Sınıflara Göre Dağılımı

\begin{tabular}{llll}
\hline 5.sınıf & 6. sinıf & $\mathbf{7 . s i n ı f}$ & $\mathbf{8 . s i n}$.f \\
\hline 3 & 3 & 2 & 1 \\
\hline
\end{tabular}

Bu araştırmanın evreni Konya ili Meram ilçesindeki ortaokul öğrencileridir. Araştırmanın örneklemi basit tesadüfi örnekleme yoluyla belirlenen beş ortaokuldan 208 öğrenciden oluşmuştur.

\subsection{Veri Toplama Araçları}

Toplumsal Değerlere Yönelik Algı Ölçeği

Araştırmada ortaokul öğrencilerin toplumsal değerlere yönelik algısı Bakaç (2013) tarafından geliştirilen 23 maddeden oluşan likert tipi ölçek "Toplumsal Değerlere Yönelik Algı Ölçeği” aracılığıyla ölçülmüştür. Ölçme aracının değerlendirilmesi belirlenen beş dereceye göre gerçekleşmiştir. Ölçeğin yapı geçerliği açımlayıcı faktör analizi yapılarak belirlenmiştir. Ölçeğin bütününe yönelik Cronbach-Alfa güvenilirlik katsayısı ise 0,86 olarak hesaplanmıştır.

Ölçme aracının maddeleri araştırmacı tarafından araştırmaya uygun olarak kısaltılmış ve güvenilirliği tekrar sağlanmıştır. Buna göre ölçeğin pilot uygulamada yapılan Cronbach-Alfa güvenilirlik katsayısı 0,88 olarak hesaplanmıştır.

Araştırmanın nitel boyutunda ise 9 öğrenciye sorulmak üzere dört soru hazırlanmıştır. Bu soruların yerindeliği ve uygunluğu konusunda eğitim bilimleri alanında çalışan üç konu alanı uzmanı öğretim üyesinin görüşü alınmıştır, bu görüşler korelasyon tekniğiyle 0.79 'luk bir ilişki bulunmuştur. Bu da araçların geçerliliği konusunda bir kanıt olarak kabul edilmiştir. Araştırmanın iç güvenilirliğini ve tutarılığını saptamak için biri Sosyal Bilgiler eğitimi alanında, diğeri psikolojik danışmanlık ve rehberlik alanında diğeri eğitim programı ve öğretimi alanında çalışan üç konu alanı uzmanı öğretim üyesinin görüşü alınmıştır, bu görüşler arasında $0.85^{\prime}$ lik bir ilişki bulunmuştur. Bu ilişki güvenilirlik katsayısı olarak kabul edilmiştir. Dış güvenilirlik açısından ise toplanan bilgiler açıkça çalışma grubuna sunulmuş, istenildiğinde ise araştırmacılara verilecek biçimde saklanmıştır. Bu sorular şunlardır:

Aileni seviyor musun? Aile senin için ne ifade ediyor? En az 5 cümleyle ifade edebilir $\operatorname{misin}$ ?

Insanlar sence her zaman dürüst olmalı mı? Neden? En az 5 cümleyle ifade edebilir misin?

Sorumluluk sahibi misin? İnsanlar sorumluluk sahibi olmazsa ne olur? En az 5 cümleyle ifade edebilir misin? 
Vatanın senin için önemli mi? Vatanın için neler yaparsın? En az 5 cümleyle ifade edebilir misin?

\subsection{Verilerin Analizi}

Araştırmanın nicel verileri SPSS 22 paket programı kullanılarak analiz edilmiştir. Araştırmada bağımsız örneklem $t$ testi tek faktörlü varyans analizi uygulanmıştır. Araştırmanın nitel boyutunda ise yarı yapılandırılmış odak grup görüşmesinde öğrencilerin verdikleri yanıtların yüzde ve frekansları analiz edilerek, betimsel analiz yönteminden faydalanılmıştır. Betimsel analiz en basit analiz şeklidir. Verilerin olduğu gibi gösterildiği, betimlendiği, resmedildiği, anlatıldığı, aktarıldığı bir irdelemedir. Ayrıntılı ve kurama dayalı bir ayrıştırma söz konusu değildir (Sönmez \& Alacapınar, 2014).

\section{BULGULAR VE YORUM}

Bu bölümde bulgulara ve onlarla ilgili yorumlara yer verilmiştir.

Bu bölümde araştırmanın birinci alt problemi olan "Meram ilçesindeki ortaokul öğrencilerinin cinsiyetlerine göre toplumsal değerleri algılama ölçeğinden aldıkları puanlar arasında anlamlı bir ilişki var mıdır?" alt problemiyle ilgili bulgular incelenmiştir. Sonuçlar Tablo 3'de bağımsız örneklem t- testiyle verilmiştir.

Tablo 3

Bağımsız Örneklem T- Testi

\begin{tabular}{cccc}
\hline Değişken & $\mathbf{T}$ & $\mathbf{T}$ & Sig. \\
\hline Aile ile iyi geçinmesek de mutlu oluruz & 16,46 & $-3,12$ & $\mathbf{0 , 0 0 2 ^ { * }}$ \\
Sorumluluklarını yerine getirmeyen insanların hayatı zorlaşır & 7,9 & 2,85 & $\mathbf{0 , 0 0 5 ^ { * }}$
\end{tabular}

Tablo 3'de bulunan t testi analizi sonuçlarına bakıldığında "Aile ile iyi geçinmesek de mutlu oluruz." ve "Sorumluluklarını yerine getirmeyen insanların hayatı zorlaşır." ifadelerinde öğrencilerin cinsiyetlerine göre toplumsal değerlere ilişkin algıları arasında anlamlı düzeyde farklılık görülmüştür $(p<0,05)$. Ortalamaya göre bağımsız örneklem t-testi sonuçları Tablo 4 'de verilmiştir.

Tablo 4

Ortalamaya Göre Bağımsız Örneklem T- Testi

\begin{tabular}{cccc}
\hline Değişken & Cinsiyet & $\mathbf{N}$ & Ort \\
\hline Aile ile iyi geçinmesek de mutlu oluruz & Kız & 112 & $\mathbf{1 , 9 3 *}$ \\
Aile ile iyi geçinmesek de mutlu oluruz & Erkek & 96 & $\mathbf{2 , 5 6 *}$ \\
Sorumluluklarını yerine getirmeyen & Kız & 111 & $\mathbf{4 , 1 7 ^ { * }}$
\end{tabular}


insanların hayatı zorlaşır

Sorumluluklarını yerine getirmeyen insanların hayatı zorlaşır

Tablo 4'de bulunan t testi sonuçlarında "Aile ile iyi geçinmesek de mutlu oluruz." ifadesinde kız öğrencilerin puan ortalaması 1,93 olup, erkek öğrencilerin puan ortalaması ise 2,56'dır. Bu durumda kız öğrenciler "Aile ile iyi geçinmesek de mutlu oluruz." fikrine katılmazken, erkekler kararsız kalmıştır. Kız öğrencilerin bu fikre katılmalarının sebebi ergenlik çağında olmaları sebebiyle aile ile ilgili başta olmak üzere her konuda daha duygusal yaklaşmaları olabilir. Sorumluluklarını yerine getirmeyen insanların hayatı zorlaşır" ifadesinde kız öğrencilerin puan ortalaması 4,17 olup, erkek öğrencilerin puan ortalaması ise 3,6'dır. Bu durumda kız öğrenciler bu fikre tamamen katılıyorken, erkek öğrenciler de kısmen katılmaktadır. Bu durumdan kızların sorumluluk değeriyle ilgili daha hassas oldukları düşünülebilir.

\section{2. İkinci Alt Probleme ilişskin Bulgular}

Bu bölümde araştırmanın ikinci alt problemi olan "Meram ilçesindeki ortaokul öğrencilerinin annelerinin eğitim durumlarına göre toplumsal değerleri algılama ölçeğinden aldıkları puanlar arasında anlamlı bir ilişki var mıdır?" alt problemiyle ilgili bulgular incelenmiştir. Sonuçlar tek faktörlü varyans analiziyle (ANOVA) Tablo 5'de verilmiştir.

Tablo 5

Tek Faktörlü Varyans Analizi (ANOVA)

\begin{tabular}{ccc}
\hline Değişken & F & Sig \\
\hline Sonunda zararlı çıkan biz olsak bile dürüstlükten ayrılmamalıyız & 4,92 & $\mathbf{0 , 0 1 *}$
\end{tabular}

Tablo 5'de bulunan sonuçlara bakıldığında "Sonunda zararlı çıkan biz olsak bile dürüstlükten ayrılmamalıyız." ifadesinde öğrencilerin annelerinin eğitim durumlarına göre toplumsal değerlere ilişkin algıları arasında anlamlı düzeyde farklılık görülmüştür $(p<0,05)$. Ortalamaya göre tek faktörlü varyans analizi (ANOVA) sonuçları Tablo 6'da verilmiştir.

Tablo 6

Ortalamaya Göre Tek Faktörlü Varyans Analizi (ANOVA)

\begin{tabular}{cccc}
\hline Değişken & Anne Eğitim Durumu & $\mathbf{N}$ & Ort \\
\hline $\begin{array}{c}\text { Sonunda zararlı çıkan biz olsak } \\
\text { bile dürüstlükten } \\
\text { ayrılmamalıyız. }\end{array}$ & ilkokul & 107 & $\mathbf{4 , 7 2 *}$ \\
& Ortaokul & 44 & 4,5 \\
& Lise & 19 & $\mathbf{4 *}$ \\
& Üniversite & 14 & 4,21
\end{tabular}


Tablo 5'de bulunan "Sonunda zararlı çıkan biz olsak bile dürüstlükten ayrılmamalıyız." ifadesinde anneleri ilkokuldan mezun olanlar öğrencilerin puan ortalaması 4,72 olup, anneleri liseden mezun olan öğrencilerin puan ortalaması ise 4 çıkmıştır. Bu durumda anneleri ilkokuldan mezun olanlar öğrenciler "Sonunda zararlı çıkan biz olsak bile dürüstlükten ayrılmamalıyız." fikrine tamamen katılıyorken, anneleri liseden mezun olan öğrenciler kısmen katılmaktadır.

Tablo 5'de bulunan $\mathrm{F}$ değerinin anlamlı çıkması ve grup sayısının 5 olması nedeniyle farkın hangi gruplar arasında olduğunu belirlemek için bağımsız gruplar t testi yapılmıştır. Bağımsız gruplar $t$ testi sonuçları Tablo 7'de verilmiştir.

Tablo 7

Bağımsız Gruplar T Testi

\begin{tabular}{cccc}
\hline Değişken & F & T & Sig. \\
\hline Sonunda zararlı çıkan biz olsak bile dürüstlükten ayrılmamalıyız & 9,7 & 3,91 & $\mathbf{0 , 0 0 *}$
\end{tabular}

Tablo 7'de bulunan bağımsız gruplar t testi sonuçlarına bakıldığında "Sonunda zararlı çıkan biz olsak bile dürüstlükten ayrılmamalıyız." ifadesinde öğrencilerin annelerinin eğitim durumlarına göre toplumsal değerlere ilişkin algıları arasında anlamlı düzeyde farklılık görülmüştür $(p<0,05)$. Ortalamaya göre bağımsız örneklem $t$ testi sonuçları Tablo 8 'de verilmiştir.

Tablo 8

Ortalamaya Göre Bağımsız Örneklem T- Testi

\begin{tabular}{ccccc}
\hline Değişken & Anne Eğitim Durumu & $\mathbf{N}$ & Ort & S.S \\
\hline $\begin{array}{c}\text { Sonunda zararlı çıkan biz olsak } \\
\text { bile dürüstlükten ayrılmamalıyız }\end{array}$ & ilkokul & 107 & $\mathbf{4 , 7 2 *}$ & 0,595 \\
& Lise & 19 & $\mathbf{4 *}$ & $\mathbf{1 , 2 9}$ \\
\hline
\end{tabular}

Tablo 8'da bulunan "Sonunda zararlı çıkan biz olsak bile dürüstlükten ayrılmamalıyız." ifadesinde anneleri ilkokuldan mezun olanlar öğrencilerin puan ortalaması 4,72 olup, anneleri liseden mezun olan öğrencilerin puan ortalaması ise 4 olarak hesaplanmıştır. Bu durumda anneleri ilkokuldan mezun olanlar öğrenciler "Sonunda zararlı çıkan biz olsak bile dürüstlükten ayrılmamalıyız." fikrine tamamen katılıyorken, anneleri liseden mezun olan öğrenciler ise bu fikre kısmen katılmaktadır. Bağımsız gruplar t testi sonuçları Tablo 9'da verilmiştir. 
Tablo 9

Bağımsız Gruplar T Testi

\begin{tabular}{|c|c|c|c|}
\hline Değişken & $\mathbf{F}$ & $\mathbf{T}$ & Sig. \\
\hline Sonunda zararlı çıkan biz olsak bile dürüstlükten ayrılmamalıyız & 6,059 & 3,36 & $0,01 *$ \\
\hline \multicolumn{4}{|c|}{ Tablo 9'daki bağımsız gruplar t testi sonuçlarına bakıldığında "Sonunda zararlı çıkan biz } \\
\hline \multicolumn{4}{|c|}{ olsak bile dürüstlükten ayrılmamalıyız." ifadesinde öğrencilerin annelerinin eğitim durumlarına } \\
\hline \multicolumn{4}{|c|}{ göre toplumsal değerlere ilişkin algıları arasında anlamlı düzeyde farklılık görülmüştür $(p<0,05)$. } \\
\hline Ortalamaya göre bağımsız örneklem t testi sonuçları Tablo 10’ & nissti & & \\
\hline
\end{tabular}

Tablo 10

Ortalamaya Göre Bağımsız Örneklem T- Testi

\begin{tabular}{ccccc}
\hline Değişken & $\begin{array}{c}\text { Anne Eğitim } \\
\text { Durumu }\end{array}$ & $\mathbf{N}$ & Ort & S.S \\
\hline $\begin{array}{c}\text { Sonunda zararlı çıkan biz olsak bile } \\
\text { dürüstlükten ayrılmamalıyız }\end{array}$ & ilkokul & 107 & $\mathbf{4 , 7 2 *}$ & 0,595 \\
& Diğer & 21 & $\mathbf{4 , 1 9 *}$ & 0,928
\end{tabular}

Tablo 10'da bulunan "Sonunda zararlı çıkan biz olsak bile dürüstlükten ayrılmamalıyız." ifadesinde anneleri ilkokuldan mezun olanlar öğrencilerin puan ortalaması 4,72 olup, anneleri diğer okullardan mezun olan öğrencilerin puan ortalaması ise 4,19 olarak hesaplanmıştır. Bu durumda anneleri ilkokuldan mezun olanlar öğrenciler "Sonunda zararlı çıkan biz olsak bile dürüstlükten ayrılmamalıyız." fikrine tamamen katılıyorken, anneleri diğer okullardan mezun olan öğrenciler ise bu fikre kısmen katılmaktadır.

\section{3. Üçüncü, Dördüncü ve Beşinci Alt Probleme ilişkin Bulgular}

Bu bölümde araştırmanın üçüncü, dördüncü ve beşinci alt problemlerine ilişkin bulgular incelenmiştir. Tek faktörlü varyans analiz (ANOVA) sonuçlarına göre anlamlı bir fark bulunmamıştır $(p<0,05)$. Bu durumda;

Meram ilçesindeki ortaokul öğrencilerinin babalarının eğitim durumlarına göre toplumsal değerleri algılama ölçeğinden aldıkları puanlar arasında anlamlı bir ilişki görülmemiştir.

Meram ilçesindeki ortaokul öğrencilerinin kardeş sayılarına göre toplumsal değerleri algılama ölçeğinden aldıkları puanlar arasında anlamlı bir ilişki görülmemiştir.

Meram ilçesindeki ortaokul öğrencilerinin karne ortalamalarına göre toplumsal değerleri algılama ölçeğinden aldıkları puanlar arasında anlamlı bir ilişki görülmemiştir.

\subsection{Nitel Probleme İlişkin Bulgular}

Öğrencilere "Toplum tarafından ortak kabul edilen değerlere (aile, dürüstlük, sorumluluk, vatan) ilişkin görüşleriniz nelerdir?” sorusu sorulmuştur. Öğrencilerin cevapları olumlu ve olumsuz olarak Tablo $11^{\prime}$ 'de verilmiştir. 
Tablo 11

Öğrencilerin Toplumsal Değerler Hakkındaki Görüşlerinin Yüzde ve Frekansları

\begin{tabular}{ccccccc}
\hline Görüşler & Aile & Dürüstlük & Sorumluluk & Vatan & Toplam & $\%$ \\
\hline Olumlu & 7 & 5 & Frekans \\
Olumsuz & 2 & 4 & 9 & 9 & 30 & 83,33 \\
Toplam & 9 & 9 & 9 & 9 & 36 & 100 \\
\hline
\end{tabular}

Öğrencilerin cevapları şu şekildedir:

E1: Aile: Onları seviyorum. Kimileri için şekersiz çayın verdiği o güzel tadı ifade ediyor benim için. Dürüstlük: tabi ki insan dürüst olmalıdır, çünkü dürüstlük insanı iyiliğe götürür. lyilikte cennete götürür. Sorumluluk: Fazla olmasa da sorumluluk sahibiyim. Hiç kimse sorumluluk sahibi olmazsa hak sahibi de olmaz. Vatan: Benim için önemlidir çünkü o benim yemeğini yediğim, suyunu içtiğim, anamın babamın toprağıdır. Dişe diş, başa baş, kanımın son damlasına kadar savaşırım.

E2: Aile: Ailemi çok seviyorum. Aile candır, huzur kaynağıdır. Onlar olmazsa hayat güzel olmaz. Dürüstlük: Bazen dürüst olmayabiliriz. Bazı zor durumlarda dürüst olunmayabilir. Sorumluluk: Evet sorumluluk sahibiyim. Insanlar sorumluluklarını bilmeli. Sorumluluklarını yerine getirmezlerse güzel şeyler olmaz. Vatan: Benim için paha biçilmez derecede önemli. Vatanım için elinden geleni yaparım.

E3: Aile: Ailemi seviyorum. Ailem benim için iyi günüm de kötü günüm de yanımda, dertleşeceğim bir arkadaş kısaca hayatımın bir parçası. Allah onları başımdan eksik etmesin. Dürüstlük: En önemli şey güvendir o yüzden dürüstlük çok önemli. insan neyse onu söylemeli. Sorumluluk: Sorumluluk sahibiyim, sorumluluklarımızı bilmezsek bir işe adım atamayız. Vatan: Vatan, bayrak millet .. Vatan için canım feda, her şeyimi veririm, gerekirse şahadet şerbeti içerim hem bu dünyada hem diğer dünyada mutlu olurum.

E4: Aile: Onları çok seviyorum: Ailem hep yanımda olur. Onlar bana değer veriyor onlarsız bir hayat düşünemiyorum. Dürüstlük: insanlar her zaman dürüst olamıyor bazen yalan söylüyoruz. Sorumluluk. Sorumluluk sahibiyim. Öyle olmasak denge bozulurdu, sağlam adımlar atamazdık. Vatan: Canım fedadır her zaman vatana. 15 Temmuzda direndiğimiz gibi her zaman direnmeli ayakta durmalıyı.

K1: Aile: Beni okutmak istemedikleri için bazen onlar sevmiyorum. Dürüstlük: Zor durumda kaldığım zaman dürüst olmayabilirim. Sorumluluk: Sorumluluk sahibiyim. Sorumluluk sahibi olmazsak akla gelebilecek tüm olumsuz şeyler olur. Vatan: Vatan benim için önemli, vatanım için her şeyi yaparım.

K2: Aile: Genelde sevsem de beni okutmak istemedikleri zamanlarda sevmiyorum. Dürüstlük: Insanlar bazen dürüst olmayabilir. Sorumluluk: Sorumluluk sahibiyim. Sana verilen 
sorumluluktur eğer bunu yerine getirmezse sorumsuzsundur. Sorumluluk olmasaydı herkes her şeyi kafasına göre yapardı. Vatan: Vatan benim için önemli misal, 15 Temmuz gecesi bütün askerlerimiz düşmana karşı savaştı ve bizim yapabileceğimiz sadece dua etmekti.

K3:Aile: Seviyorum ailemi. Ailem benim için olmazsa olmazlardan biridir. Dürüstlük: Dürüstlük olmalıdır ama bazen değil çünkü her zaman dürüst olmayı başaramayız. Sorumluluk: Sorumluluk sahibiyim. Vatan: Benim için her şeyden önemlidir vatan. Çünkü vatanım olmazsa ailemde olmazdı belki bizler de olmazdık.

K4:Aile: Ailemi seviyorum. Çünkü ben ailem olmazsa yapayalnız olurum. Annesi babası olmayanların ne düşündügünü bilemeyiz. Dürüstlük: Insanlar dürüst olursa cennete gider dürüstlük önemlidir. Sorumluluk: Doğruyu iyiden iyi kötüden ayıramaz. Neyin nasıl olduğunu sorumluluk olmazsa bilemeyiz. Vatan: Vatan benim için çok önemli. 15 Temmuz da direndiğimiz gibi sonuna kadar direnirim. Canımı feda ederim.

K5: Aile: Ailemi seviyorum tabi, ailem benim için hayatım, her şeyim onlar olmasaydı çok mutsuz yalnız olurdum. lyi ki varlar. Onların olmadığı bir hayat düşünemiyorum. Dürüstlük: Insanlar dürüst olmalı ama bunu başarmak zordur. Sorumluluk: Insanlar sorumluluk sahibi olmazsa kötü şeyler olur sorumluluk sahibi olmalıyız. Vatan: Her şeyden daha önemli, canımı bile veririm, her şeyimi feda ederim.

Bu verilere göre öğrencilerin aile ile görüşlerinin çoğu olumludur. Bununla beraber bir kısım öğrenci genellikle ailesi onları okutmayı istemedikleri için olumsuz görüş vermiştir. Öğrencilerin çoğu dürüst olmanın önemli olduğunu ifade ederken, bir kısmı ise dürüst olmanın her zaman mümkün olamayacağını ifade etmiştir. Sorumluluk ve vatan toplumsal değerleri öğrenciler tarafından önemli olarak ifade edilmiş, hayata devam etmek için bu değerlerin olmazsa olmaz olduğu belirtilmiştir.

\section{TARTIŞMA SONUÇ VE ÖNERILER}

Bu araştırmanın amacı ortaokul öğrencilerin toplumsal değerlere yönelik bakış açılarını ortaya çıkarmaktır. Bu amaç doğrultusunda yapılan araştırmanın sonuçlarına göre; Meram ilçesindeki ortaokul öğrencilerinin cinsiyetlerine göre toplumsal değerleri algılama ölçeğinden aldıkları puanlar arasında anlamlı bir ilişki görülmüştür. Öğrencilerin cinsiyetlerine göre toplumsal değerlere verdikleri önemin değiştiği görülmektedir. Sonuçlara göre aile ile iyi geçinemeyen ama bundan mutsuz olmayan öğrenciler kız ve erkek gruplar arasında aynı değildir. Bununla beraber sorumluluklarını yerine getirmeyen insanların hayatlarının zorlaşacağı fikri kız ve erkekler arasında farklılık göstermiştir. Araştırmanın sonuçlarına göre aile ve sorumluluk değerlerinin cinsiyete göre farklı anlamlar taşıdığını görülmektedir. Gömleksiz ve Cüro (2011) tarafından yapılan araştırmanın sonuçlarına göre kız öğrencilerin sorumluluğa ilişkin tutumlarının erkek öğrencilere göre daha olumlu olduğu ortaya çıkması açısından bu çalışmayla benzerlik göstermektedir. Ayrıca Keskin'in (2008) Sosyal Bilgiler dersinde yer alan sorumluluk ve çalışkanlık değerlerini kız öğrencilerin erkek öğrencilere göre daha çok benimsedikleri araştırma sonucuyla uyum içerisindedir. 
Literatürde değerler ve cinsiyet arasındaki ilişkileri inceleyen başka çalışmalara rastlanmaktadır. Uyguç (2003) tarafından yapılan çalışmaya göre kız öğrencilerin hem toplulukçu ve dişil değerlere hem de eril ya da erkeksi değerlere, erkek öğrencilerden, daha çok önem verdikleri dikkat çekmektedir. Ayrıca, Aydın (2005), Gömleksiz (2007) ve Bulut (2012) tarafından yapılan çalışmalarda kız ve erkek öğrencilere göre değerlerin değiştiği görülmektedir. Bunun tam tersi olarak Yapıcı ve Zengin (2003) ve Özkul (2007) tarafından yapılan çalışmalara göre cinsiyetin değer tercihlerinde etkili bir rol oynamadığı görülmüştür.

Bolat (2011) Gazi üniversitesi meslek yüksek okulu öğrencilerinin sosyal değerlere ilişkin görüşlerinin öğrenmek amacıyla yaptığı çalışmanın sonucunda kız öğrencilerin, erkek öğrencilere göre aile değerleri boyutuna ilişkin görüşleri daha olumlu bulunmuştur. İstatistiksel olarak da kız öğrenciler ile erkek öğrencilerin göre aile değerleri boyutuna ilişkin görüşleri arasında anlamlı bir fark bulunması bu çalışmanın sonuçlarıyla benzerlik taşımaktadır. Akbaş’ın (2004) yaptığı çalışma aileye verilen değer açısından bu çalışmayla benzerlik göstermektedir. Akbaş (2004) tarafından yapılan çalışmanın sonuçlarına göre, ilköğretim 8. sınıf öğrencilerinin, ilköğretim genel hedeflerinde belirtilen değerlere ulaşma düzeylerini, öğrenci ve öğretmen görüşlerine göre değerlendirmiş ve araştırma sonucunda aileye önem verme ve güvenilir olma gibi geleneksel değerleri; saygılı ve hoşgörülü olma gibi demokratik değerleri; temiz olma gibi temel değerleri öğrenciler tarafından okullarda olması gerektiği ifade edilmiştir. Yiğittir (2009) tarafından yapılan araştırmanın sonucu ise bu çalışmadan aile değeri açısından farklılık göstermektedir. Yiğittir (2009) tarafından yapılan araştırmanın sonucuna göre; ilköğretim öğrenci velilerinin değer tercihleri ile ilgili çalışmasında onların okulda en çok aile birliğine önem verme, çalışkanlık, bayrağa ve İstiklal Marşına saygı, vatanseverlik, sorumluluk, dürüstlük, doğruluk, saygı, yardımseverlik ve cesaret değerlerine öncelik verdiklerini tespit etmiştir. Bu değerlerden saygı, dürüstlük, çalışkanlık ve yardımseverliğin öğrencilerce de tercih edildiği görülmüştür.

Araştırmanın bir diğeri sonucuna göre Meram ilçesindeki ortaokul öğrencilerinin annelerinin eğitim durumlarına göre toplumsal değerleri algılama ölçeğinden aldıkları puanlar arasında anlamlı bir ilişki görülmüştür. Öğrencilerin annelerinin eğitim durumlarına göre toplumsal değerlere verdikleri önemin değiştiği görülmektedir. Öğrencilerin "Eğer kişiye zarar verecekse dürüst olmaya gerek yok." yaklaşımıyla anneleri liseden mezun olan öğrenciler kısmen "Sonunda zararlı çıkan biz olsak bile dürüstlükten ayrılmamalıyız." ifadesine kısmen katılması benzerlik göstermektedir. Bu değerin anneleri liseden, ilkokuldan ve diğer kurumlardan mezun olan öğrenciye göre değiştiği görülmektedir. Öngen ve Aytaç (2013) tarafından yapılan çalışmada annenin çalışma durumunun öğrencilerin toplumsal cinsiyet rolüne yönelik tutumları üzerinde etkili olduğu bulunmuştur. Ancak Bolat (2011) tarafından yapılan çalışmanın sonucuna göre, meslek yüksekokulu öğrencilerin annelerinin eğitim durumlarına göre sosyal değerlere ilişkin görüşleri farklılaşmaması açısından bu araştırmadan farklılık göstermektedir.

Araştırmanın başka bir sonucu; Meram ilçesindeki ortaokul öğrencilerinin babalarının eğitim durumlarına göre toplumsal değerleri algılama ölçeğinden aldıkları puanlar arasında anlamlı bir ilişki görülmemesidir. Öğrencilerin babalarının eğitim durumlarına göre toplumsal 
değerlere verdikleri önemin değişmediği görülmektedir. Çetin (2016) tarafından yapılan araştırma öğrencilerin toplumsal değerlere ilişkin algıları açısından bu çalışmayla benzerlik göstermektedir. Çetin (2016) tarafından yapılan araştırmanın sonucunda bulgular incelendiğinde toplumsal değer algılarının cinsiyet, anne eğitim düzeyi, günlük TV izleme süresi ve izlenen program türüne göre anlamlı bir farklııık göstermediği görülmektedir. Kardeş sayısı, baba eğitim düzeyi, aile gelir düzeyi ve yaşanan yer değişkenlerine göre ise anlamlı bir farklılık bulunmuştur. Ayrıca, Bolat (2011) tarafından yapılan çalışmayla bu çalışma meslek yüksekokulu öğrencilerinin babalarının eğitim durumlarına göre sosyal değerlere ilişkin görüşleri farklılaşmamaktadır. Bolat (2011) tarafından yapılan çalışma ve bu çalışma iki grubunda babalarının eğitim durumlarına göre sosyal değerlere ilişkin görüşleri açısından paralellik göstermektedir.

Meram ilçesindeki ortaokul öğrencilerinin kardeş sayılarına göre toplumsal değerleri algılama ölçeğinden aldıkları puanlar arasında anlamlı bir ilişki görülmemiştir. Illğan, Karayiğit ve Çetin (2013) tarafından yapılan araştırmanın sonucuna göre demografik değişkenlerden anne ve babanın eğitim düzeyinin, çalışma durumunun, ailenin aylık gelirinin ve kardeş sayısının öğrencilerin demokratik değerlerini iki boyut hariç farklılaştırmadığı sonucuna ulaşılmıştır. ilğan, Karayiğit ve Çetin (2013) tarafından yapılan çalışma bu çalışmayla değerlerin babanın eğitim düzeyinin ve kardeş sayısına göre anlamlı bir fark göstermemesi açısından benzerlik gösterirken; annenin eğitim düzeyi açısından anlamlı bir fark göstermemesi açısından farklılık göstermektedir. Kurt (2015) tarafından yapılan araştırmada Gedik Üniversitesi Gedik Meslek Yüksek Okulu çalışanlarında var olan bireysel değer yönelimleri, çeşitli değiş̧enler açısından incelenmiştir. Araştırmada çalışanların eğitim düzeyleri ve kardeş sayılarına göre bireysel değer yönelimlerinin farklılaşması açısından bu çalışmadan sonucu farklıdır.

Meram ilçesindeki ortaokul öğrencilerinin karne ortalamalarına göre toplumsal değerleri algılama ölçeğinden aldıkları puanlar arasında anlamlı bir ilişki görülmemiştir. Sadıkoğlu (2013) 6. sınıf Sosyal Bilgiler programında doğrudan kazandırılacak değerlerin öğrenciler tarafından bilişsel öğrenilmişlik düzeylerini incelemiştir. Araştırmada doğrudan kazandırılacak değerlere yönelik bilgi düzeylerini karne ortalaması içinde olmak üzere birçok değişkene göre değişip değişmediğini tespit etmiştir. Sadıkoğlu (2013) tarafından yapılan çalışmanın sonucunda bir önceki yıl Sosyal Bilgiler dersi karne notu farklı olan öğrenciler arasında doğrudan kazandırılacak değerlerin öğrenciler tarafından bilişsel öğrenilmişlik düzeyleri başarı puanı açısından istatistiksel olarak anlamlı fark bulunması açısından bu çalışmadan farklılık göstermektedir.

Araştırmadaki nitel verilerden elde edilen sonuçlara göre; Meram ilçesindeki ortaokul öğrencilerinin aile ile görüşlerinin çoğu olumludur. Öğrencilerin çoğu dürüst olmanın önemli olduğunu ifade etmiştir. Aynı zamanda sorumluluk ve vatan toplumsal değerleri öğrenciler açısından gerekli bulunmuştur. Yurt içinde Tay'ın (2009) sınıf ve sosyal bilgiler öğretmeni adayları ile yaptığı araştırmada öğretmen adaylarının ifade ettiği saygı, sevgi, vatanseverlik, dürüstlük, ahlak, inanç, hoşgörü, bilimsellik, aile birliğine önem verme, kültürel değerlere önem verme, çevre bilinci, Atatürkçülük, bayrak sevgisi, temizlik ve estetik değerleri 4, 5, 6 ve 7 . sınıf öğrencileri tarafından da ifade edilmiştir. Tay (2009) tarafından yapılan çalışma öğrencilerin 
milli değerlerden biri sayılan vatan değerine ilişkin öğrencilerin görüşleri açısından bu araştırmayla benzerlik göstermektedir. Ayrıca Yiğittir'in (2010) çalışmasında da Sosyal Bilgiler dersi öğretim programında milli ve geleneksel değerlerin doğrudan verilmesi gereken değerler olarak benimsendiği sonucuna ulaşması bu çalışmada yer alan milli değerlerden biri olan vatan değerine ilişkin sonuçlar açısından benzerlik göstermektedir. Yıldırım (2009) tarafından yapılan çalışmada sınıf öğretmenlerinin değerler eğitimine ilişkin görüşleri alınarak, sınıf öğretmenlerinin değerlerin kazandırılması süreci ile ilgili düşünce ve deneyimlerinin betimlenmesi amaçlanmıştır. Çalışma, Kırşehir ili merkeze bağlı orta sosyo-ekonomik düzeydeki üç devlet ilköğretim okulunda yürütülmüştür. Araştırmanın verileri odak grup görüşmeleri yoluyla toplanmıştır. Araştırma sonuçlarına göre; öğretmenlerin çocuklara kazandırması gereken değerler arasında vatanseverlik değerini ön plana çıkması bu çalışmayla büyük ölçüde benzerlik taşımaktadır. Karaduman (1985) tarafından Ankara'da sosyo-ekonomik düzeyi farklı üç lisede yapılan bir araştırmada lise gençlerinin değerleri tespit edilmiştir. Araştırma sonucunda özgürlük, hayatta başarılı olmak, dürüstlük, sağlık ve geniş görüşlülük bütün sosyoekonomik seviyelerde, yaş gruplarında ve iki cinsiyette de önemli bulunmuştur. Önemsiz gösterilen değerler ise aşk (manevi yakınlık), güzel kirletilmemiş bir doğa, aile güvenliği, dini inanç, cinsellik, itaat ve hırstır. Karaduman (1985) tarafından yapılan araştırmayla bu araştırmanın sonucu dürüstlü değerine verilen önem açısından benzerlik gösterse de aileye verilen önem açısından farklılıklar göstermektedir. Tezcan (1974) yaptığı çalışmada değer kavramını ele almış ve Türk toplumunun değer haritasını ortaya çıkarmıştır. Araştırma sonuçlarına göre; öğrencilerin çoğunluğu modası geçmiş değerler olarak; geleneklere ve toprağa bağlıık, dindarlık, yiğitlik-mertlik değerlerini seçmiştir. Araştırmaya göre günümüzde hala geçerli olan değerler ise namus-şeref, dürüstlük, ahlak, tahsil, bilgi, yurtseverlik, bireysel özgürlük, maddiyat, seksilik, sadakat olarak belirlenmiştir. Tezcan (1974) tarafından yapılan çalışmayla bu çalışmanın sonuçları yurtseverlik, dürüstlük değerleri açısından benzerlik göstermekte olup bu değerlerin hala benimsendiğini göstermektedir.

Yurt dışında ise Bulach (2002) hangi değerlerin öğretilmesinin gerektiğine ilişkin bir araştırma yapmıştır. Araştırmacı Georgia eyaletindeki anne-babalar, öğretmenler ve din adamlarından toplum tarafından değer olarak nitelendirilen 16 karakter özelliğini sıralamalarını istemiştir. Öğretmenler ve aileler diğerlerine, kendilerine ve mülkiyete saygının, dürüstlük ve öz denetim değerlerinin öğretilmesinin önemli olduğunu belirtmişlerdir. Din adamları ise motivasyon, empati ve azimi önemli üç değer olarak görmüşlerdir. Bulach(2002)tarafından yapılan çalışmayla bu çalışmanın dürüstlük değerinin önemsenmesi açısından benzerlikler göstermektedir. Whitney (1986) tarafından yapılan çalışmada Amerika' nın bir eyaletinde bulunan devlet liselerinde uygulanan değer eğitiminin düzeylerini araştırılmıştır. Araştırma, bu eyalette bulunan 207 okuldan rastgele seçilen 75 okuldaki Sosyal Bilgiler öğretmenleri ile yapılmıştır. Bu öğretmenlere anket uygulanmıştır. Anket sonuçlarına göre öğretmenlerin en çok öğrettikleri değerlerin dürüstlük, saygı ve sorumluluk olduğu sonuçlarına ulaşılması bakımından bu çalışmada öne çıkan değerlerin başka toplumlarda da benimsendiği görülmektedir. Bulach ve Butler (2002) tarafından yapılan çalışmada 16 karakter değeri ile ilgili davranışların varlığı ya da yokluğunu belirleyen bir yöntem geliştirilmiştir. 16 grupta toplanan karakter değerleri şunlardır: Saygı, dürüstlük, kendine hakim olma (otokontrol), sorumluluk, 
işbirliği, doğruluk, şefkat, sebat (azim), merhamet, nezaket, bağışlama, vatanseverlik, hoşgörü, alçakgönüllülük, mertlik ve sportmenliktir. Elde edilen veriler ışığında en fazla ortaokul ve liselerde olmak üzere saygı, nezaket, bağışlama ve alçakgönüllülük değerlerine yönelik karakter eğitimi programlarına intiyaç vardır. Illköğretim düzeyinde ise, nezaket, mertlik ve sportmenlik değerlerine ihtiyaç olduğu saptanmıştır. Bu çalışmanın sonucunda önemli görülen değerlerle Bulach ve Butler (2002) tarafından yapılan çalışmanın sonucunda önemli görülen değerler arasında farklılıklar görülmektedir.

Bu sonuçlara göre şu önerilerde bulunulmuştur.

(1) Bu çalışma sadece Konya ili Meram ilçesinde ve ortaokul öğrencileri üzerinde yapılmıştır. Tüm toplumun yapısını ölçmek için başka bölgelerde ve kademelerde de yapılabilir. Farklı ortaokullar üzerine yapılıp elde edilen sonuçlar ortaokullar arası toplumsal değer farklılıklarını ve benzerliklerini ortaya çıkartmak için karşılaştırılabilir.

(2) Bu çalışmada temel olarak dört toplumsal değer üzerinde çalışılmıştır. Diğer toplumsal değerler üzerinde de çalışarak ortaokul öğrencilerin toplumsallaşmasına fayda sağlanabilir.

(3) Bu çalışma öğrencilerin toplumsal değerlere bakış açısını anlamaya yöneliktir. Bu değerleri geliştirmeye yönelik bir değer eğitimi programı geliştirilebilir.

(4) Öğrencilere kazandırılacak değerler okul öncesi eğitimden başlayıp süreklilik gösterecek şekilde düzenlenmeli ve bu değerler eğitim programlarında açıkça belirtilmelidir. Buna yönelik olarak da tüm kurumlarda öğrencileri değerlerini ve değer yönelimlerini belirlemeye yönelik çalışmalara yer verilmelidir.

\section{KAYNAKLAR}

Akbaş, O. (2004). Türk milli eğitim sisteminin duyuşsal amaçlarının ilköğretim II.kademede gerçekleşme derecesinin değerlendirilmesi. (Yayınlanmamış Doktora Tezi). Gazi Üniversitesi, Ankara.

Akbaş, O. (2008). Değer eğitimi akımlarına genel bir bakış. Değerler Eğitimi Dergisi. 6(16), 9-27.

Akyüz, Y. (2008). Türk eğitim tarihi. (12. Baskı). Ankara: Pegem Akademi Yayıncılık.

Alan, Y. (2014). Değerler eğitimi açısından Kur'an Kıssaları'nın Türkçe ders kitaplarında kullanılması. Sosyal Bilimler Dergisi. 4(8), 61-76.

Ayaz, H. (2015). Bülbül şiiri etrafında Mehmed Âkif'in değerler dünyası üzerine düşünceler. Fırat Üniversitesi Sosyal Bilimler Dergisi. 25(1), 32-37.

Aydın, A. (2005). Dil ve tarih coğrafya fakültesi öğrencilerinin değer hiyerarşileri ile ilahiyat fakültesi öğrencilerinin değer hiyerarşilerinin karşılaştırılması.(Yayınlanmamış Yüksek Lisans Tezi). Ankara Üniversitesi ,Ankara.

Aydın, Z. ve Gürler, Ş. (2014). Okulda değerler eğitimi-yöntemler, etkinlikler, kaynaklar. Ankara: Nobel Akademik Yayıncılık.

Bacanlı, H. (2005). Duygusal davranış eğitimi. Ankara: Nobel Yayın Dağıtım.

Bakaç, E. (2013). Toplumsal değerlere yönelik algı ölçeği: Geçerlilik ve güvenilirlik çalışması. Eğitim ve Öğretim Araştırmaları Dergisi. 2(4), 303-309. 
Başol, N. (2016). Osmanlı dönemi kadın divan şairlerinden Mihri Hatun Divanı'nın söz varlığı unsurları ve değerler eğitimi bağlamında incelenmesi. (Yayımlanmamış Yüksek Lisans Tezi). Gazi Üniversitesi, Ankara.

Baydar, P. (2009). Illköğretim beşinci sınıf sosyal bilgiler programında belirlenen değerlerin kazanım düzeyleri ve bu süreçte yaşanılan soruların değerlendirilmesi.(Yüksek Lisans Tezi). Çukurova Üniversitesi, Adana.

Bolat, Y. (2011). Gazi üniversitesi meslek yüksekokulu öğrencilerinin sosyal değerlere bakışları. (Yüksek Lisans Tezi). Gazi Üniversitesi, Ankara.

Bolat, Y. (2016). Sosyal değerleri ve değerler eğitimini anlamak. Akademik Sosyal Araştırmalar Dergisi. 29, 322-348.

Bulach, C. R. (2002). Implementing a character education curriculum and assessing its impact. The Clearing House, 76(2), 79-83.

Bulach, C.R. , Butler J.D. (2002). The occurence of behaviors associated with sixteen character values. Journal of Humanistic Counseling, Education and Development, 41, 200-214.

Bulut, S.S. (2012). Gazi eğitim fakültesi öğrencilerinin değer yönelimleri. Uluslararası Türkçe Edebiyat Kültür Eğitim Dergisi, 3 (1), 216-238.

Canatan, A. (2008). Toplumsal değerler ve yaşılıar. Yaşılı Sorunları Araştırma Dergisi. 1, 62-71.

Ceylan, Y. (2012). Toplumsal değerler ve medya etiği. Dicle Üniversitesi Sosyal Bilimler Enstitüsü Dergisi. 4, 45-58.

Çetin, H. (2016). Dördüncü sınıf öğrencilerinin toplumsal değer algılarının incelenmesi. (Yayımlanmamış Yüksek Lisans Tezi). Çukurova Üniversitesi, Adana.

Demirtaş, C. (2010). Öğretmen ve geleceğimiz. Bilim ve Aklın Aydınlığında Eğitim. 130, 2-40.

Dilmaç, B. , Arıcak, .O.T. (2012). Değerler ölçeği geçerlilik ve güvenirlik çalışması. 2. Uluslararası Değerler Eğitimi Sempozyumu. Değerler Eğitimi Merkezi, 16 - 18 Kasım 2012, İstanbul.

Dilmaç B. , Bircan, H. H. (2014). Değerler ve değerler psikolojisi (1. Baskı). Ankara: Pegem Akademi.

Kurt. E. (2015). İ̧̧ yaşamında bireysel değerler: Bir vakıf üniversitesi meslek yüksek okulu örneği. Elektronik Mesleki Gelişim ve Araştırmalar Dergisi, 3(1),18-36.

Ersoy, B. (2006). Toplumsal değerler ve çalışanların iş doyumu arasındaki ilişki: Ampirik bir uygulama. Yüksek Lisans Tezi. Dumlupınar Üniversitesi, Kütahya.

Ertürk, S.(1975). Eğitimde program geliştirme. Ankara: Yelkentepe Yayınları.

Fidan, N. (2012). Okulda öğrenme ve öğretme (3. Baskı). Ankara: Pegem Akademi Yayıncılık.

Gömleksiz, M. N. (2007). Lise öğrencilerinin toplumsal değerlere ilişkin tutumları: Elazı̆̆ ili örneği. R. Kaymakcan, S. Kenan, H. Hökelekli, Z. Arslan, ve M. Zengin (Ed.), Değerler ve eğitimi içinde (s. 727-741). İstanbul: Değerler Eğitimi Merkezi Yayınları.

Gömleksiz, M. N., Cüro, E. (2011). Sosyal bilgiler dersinde yer alan değerlere ilişkin öğrenci tutumlarının değerlendirilmesi. Uluslararası Insan Bilimleri Dergisi, 8(1), 96-130.

Güngör, E. (2000). Değerler psikolojisi üzerine araştırmalar. İstanbul: Ötüken Yayınları.

ilğan, Karayiğit vd. (2013). Ortaokul öğrencilerinin demokratik değerlere sahip olma düzeylerinin çeşitli değişkenlere göre incelenmesi. Sosyal Bilimler Dergisi, 11(2), 97118. 
Kan, Ç. (2010). Sosyal bilgiler dersi ve değerler eğitimi. Milli Eğitim Dergisi, 187, 138-145.

Karaduman, M. (1985). 15-19 yaşlarındaki lise öğrencilerinin değer sıralaması. (Yayınlanmamış Yüksek Lisans Tezi). Ankara Üniversitesi, Ankara.

Karasar, N. (2006). Bilimsel araştırma yöntemi (16. Baskı). Nobel Yayın Dağıtım, Ankara.

Keskin, Y. (2008). Türkiye'de sosyal bilgiler öğretim programlarında değerler eğitimi: Tarihsel gelişim, 1998 ve 2004 programlarının etkililiğinin araştırılması. (Yayınlanmamış Yüksek Lisans Tezi). Marmara Üniversitesi, İstanbul.

Kirmanoğlu, B. (2016). Değerler eğitiminin ilkokul toplum hizmeti uygulamalarına etkisi. (Yayımlanmamış Doktora Tezi). Giresun Üniversitesi, Giresun..

Lihua, Z. (2013, Kasım 21). China's Tradıtıonal Cultural Values. http://carnegietsinghua.org/publications/?fa=53613 (Erişim Tarihi: 2016, 10 Aralık).

Michealis J. U. ve Garcia, J. (1996). Social studies for children a guide to basic instruction (11.ed.). Allyn and Bacon: Boston

Milli Eğitim Bakanlığı (MEB). (1948). Illkokul programı. İstanbul: Milli Eğitim Basımevi.

Milli Eğitim Bakanlığı (MEB). (1968). İlkokul programı. İstanbul: Milli Eğitim Basımevi.

Öngen, B., Aytaç, S. (2013). Üniversite öğrencilerinin toplumsal cinsiyet rollerine ilişkin tutumları ve yaşam değerleri ilişkisi. Sosyoloji Konferanslar Dergisi, 48 (2), 1-18.

Özkul, A. S. (2007). Yaşam ve çalışma değerlerini etkileyen faktörler SDÜ öğrencileri üzerine bir araştırma.(Yayınlanmamış Yüksek Lisans Tezi). Süleyman Demirel Üniversitesi, Isparta.

Rokeach, M, (1973). The nature of human values. New York: The Free Press

Sadıkoğlu, N. (2013). 6. sınıf sosyal bilgiler programında doğrudan kazandırılacak değerlerin öğrenciler tarafından bilişsel öğrenilmişlik düzeyleri.(Yüksek Lisans Tezi). Ahi Evran Üniversitesi, Kırşehir.

Spranger, E. (1928). Types of men. Halle: Max Neimeyer.

Sönmez,V. , Alacapınar, F. G. (2014). Örneklendirilmiş bilimsel araştırma yöntemleri (3. Baskı). Ankara: Anı Yayıncılık.

Tezcan, M. (1974). Türklerle ilgili stereotipler (kalıp yargılar) ve Türk değerleri üzerine bir deneme. Ankara: A.Ü Eğitim Fakültesi Yayınları:44.Ankara Üniversitesi Basımevi.

Tezcan, M. (1987). Kültür ve kişilik. Ankara: Bilim Yayınları.

Turan, S. ve Aktan, D. (2008). Okul hayatında var olan ve olması düşünülen sosyal değerler. Türk Eğitim Bilimleri Dergisi, 6(2), 227-259.

Türk Dil Kurumu (TDK). (2007). Güncel Türkçe sözlük ve yazım kılavuzu etkileşimli yoğun diski. Ankara: Türk Dil Kurumu Yayınları.

Türkkahraman, M. (2014). Social values and values education. Procedia-Social and Behavioral Science. 116, 633-638.

Ulusoy, K. ve Arslan, A. (2016). Değerli Bir kavram olarak değer ve değerler eğitimi. R. Turan ve K. Ulusoy (Ed.), Farklı Yönleriyle Değerler Eğitimi içinde (s. 1-16), Ankara: Pegem Akademi.

Uyguç, N. (2003). Cinsiyet, bireysel değerler ve meslek seçimi. D.E.Ü.i.i.B.F.Dergisi,8(1), 93-103. 
Uysal, F. (2008). Karakter eğitim programlarının değerlendirilmesi. (Yüksek Lisans Tezi). Yeditepe Üniversitesi, İstanbul.

Tay, B. (2009). Prospective teachers' views concerning the values to teach in the course of social sciences. Procedia-Social and Behavioral Sciences, 1(1), 1187-1191.

Whitney, I.B.(1986). The status of values education in the middle and junior high schools of Tennessee. (Doktora Tezi). Tennessee State University, ABD.

Yapıcı, A. ve Zengin, Z. S. (2003). İlâhiyat fakültesi öğrencilerinin değer tercih sıralamaları üzerine psikolojik bir araştırma: Çukurova. Değerler Eğitimi Dergisi, 1(4), 173-206.

Yaşar, Ş. (2008). Sosyal Bilgiler ve dünya vatandaşlığı. Ş. Yaşar (Ed.), Hayat Bilgisi ve Sosyal Bilgiler Öğretimi içinde (s. 229-245), Eskişehir: Anadolu Üniversitesi Açıköğretim Fakültesi Yayınları.

Yıldırım, K. (2009). Values education experiences of Turkish class teachers: A phenomeonological approach. Eğitim Araştırmaları- Eurasian Journal of Educational Research, 35, 165-184.

Yiğittir, S. (2009). ilköğretim sosyal bilgiler dersi 4 ve 5. sınıf değerlerinin kazanılma düzeyi. (Yayımlanmamış Doktora Tezi). Gazi Üniversitesi, Ankara.

Yiğittir, S. (2010). İlköğretim öğrenci velilerinin okullarda kazandırıımasını arzuladığı değerler. Değerler Eğitimi Dergisi, 8(19), 207-223. 


\section{SUMMARY}

Education has been defined differently so far. Education is process of changing behaviour in an individual's behaviour on request and through his/her experince according to Ertürk (1975). According to Fidan (2012) education is process of growing people as specific goals. As a result, education can be defined all of the changes and implementations for the purpose of acquiring some goals. Education institutions where education has been performed are responsible for some duties such as teaching values which expressed cleary or closely, discipline students according to specific rules, contrubite moral development (Akbaş, 2008). So it can be said that values are in the aaffetive dimension of education and in aims of education programmes. Like there is no common idea about the meaning of values, there is no common idea about the classification of values, Values have been classifed as different ways so far.

Despite a lot of researchers have been conducted about values, there is no common idea about the meaning of values. Values is expressed as" abstract scale which is used for determining the importance of something" (TDK, 2007). Also value is defined as electing something to something (Uysal, 2008), so value can be expressed a compare means. According to Spranger (1928) values have been grouped as academic values, economic values, esthetics values, social values, politic values, religious values. Also Güngör (2000) has added moral values to these values. Dilmaç and Arıcak ( 2012) has classfied values as social values, career values, intellectual values, spritual values, materialistic values, honor of humanity, romantic values, freedom and futuwwat/munificence\&courage.

The different classification of values have been seen. Despite different classification, some values like social values which shared by most of society to make a better society (Türkkahraman, 2014). Social values which save long years are cultural fruits of society. They are provisions which determine people what they do in society. Social values are like fingerprint and they constitute the root of people behaviour (Canatan, 2008). We can understand that social values can integrate with society. Social values have some duties such as evaluation the social importance of groups and individuals, showing individuals where they have been placed in society according to others perspective, specifying requested style of behaviour in society, providing social solidarity which guide social roles (Tezcan 1987).

We can understand that social values are connected with people; they affect closely society and individuals. The purpose of this study is to identify the students' perceptions of social value. The study was carried 208 students on five school by random in Meram in Konya in 2016-2017 education year. Mixed method which is used both quantitative method and qualitative method is used in this research. The scale of students' perceptions of social value was used in quantitative part of research, four questions which prepared by researcher were used qualitative method part of research. Data is analyzed with independent samples t-test, ANOVA and descriptive analysis. According to the findings, it is found that there is a significant difference between the students' perceptions of social values and their genders, mother's educational background but there is not a significant difference between the students' perceptions of social values and their father's educational background, the number of sister/brother, average of school report. 